\title{
New Grounds for Malay
}

Intercultural implications of Malaysia's emerging role as Hub for international Higher Education and Industry 4.0

\author{
Arndt Graf \\ Goethe University Frankfurt, Germany + Universiti Pendidikan \\ Sultan Idris, Malaysia \\ arndtgraf@yahoo.de
}

\begin{abstract}
Before the Covid-19 pandemic deeply impacted the economies and societies of Southeast Asia, Malaysia had achieved many of the goals formulated in the so-called "Vision 2020" during the era of Prime Minister Dr. Mahathir Mohamad (1981-2003). As this long-term development program emphasized strongly on knowledge society (k-society), knowledge economy (k-economy) and Information and Computer Technology (ICT), one important legacy of this era was the establishment of numerous excellent academic programs, including in technological disciplines. The post-Mahathir administrations since the early 2000s built on this asset and successfully transformed the country's Higher Education sector further, so that it attracted hundreds of thousands of international students from the early 2000s until the beginning of the Covid-19 crisis in early 2020 . This paper examines the linguistic and cultural implications of Malaysia's emerging role of as hub of both international Higher Education and Industry 4.0 .
\end{abstract}

KEYWORDS: Malaysia, international student mobility, Industry 4.0, Africa

Zusammenfassung: Bevor die Covid-19-Pandemie auf die Wirtschaften und Gesellschaften Südostasiens tiefe Auswirkungen hatte, hatte Malaysia viele der Ziele erreicht, die in der sogenannten „Vision 2020“ während der Ära des Premierministers Dr. Mahathir Mohamad (1981-2003) 
formuliert worden waren. Da dieses langfristige Entwicklungsprogramm einen starken Schwerpunkt auf die Wissensgesellschaft (k-society) und die Wissens-Wirtschaft (k-economy) gelegt hatte, war ein bedeutendes Erbe dieser Ära die Errichtung zahlreicher exzellenter akademischer Programme, einschließlich in technischen Disziplinen. Die Post-MahathirÄra seit den frühen 2000er Jahren baute auf dieser Grundlage auf und transformierte den Sektor des Hochschulwesens des Landes weiter, so dass es von den frühen 2000er bis zu Beginn des Jahres 2020 hunderttausende international Studierende anzog. Dieser Beitrag untersucht die sprachlichen und kulturellen Implikationen von Malaysias zunehmender Rolle als Drehscheibe sowohl von internationaler Hochschulbildung als auch von Industrie 4.0.

SCHLÜSSELWörTER: Malaysia, internationale Studierendenmobilität, Industrie 4.0, Afrika

\section{Introduction}

Since the independence of Malaya in 1957, and the foundation of Malaysia in 1963, the country experienced extended periods of political stability and economic growth. During the long rule of Prime Minister Dr. Mahathir Mohamad (1981-2003), the government emphasized on a long-term development program under the name "Vision 2020". The main objective was to become a fully developed country by 2020, focusing on Information and Computer Technology (ICT) as the main technology. When Dr. Mahathir Mohamad was again Prime Minister, from 2018-2020, he declared that Malaysia had achieved many aspects of Vision 2020, although the vision was not fully realized. ${ }^{1}$ In 2021, he even stated that Malaysia had failed to reach the goals of Vision 2020 ("Mission unrealized"). ${ }^{2}$

Despite this recent skeptical view of the politician who had engineered and implemented the grand strategy of "Vision 2020" from the beginning,

1 https://www.malaysiakini.com/news/506060

2 https://www.theedgemarkets.com/article/vision-2020-mission-unrealised-dr-m-race-and-religiongot-way-bangsa-malaysia-under-vision 
Malaysia in early 2020, before it was deeply affected by the Covid-19 pandemic, had achieved a role as an emerging hub for International Higher Education and Industry 4.0. From the early 2000s onwards, hundreds of thousands of international students have studied in Malaysia, among them tens of thousands of African students, and often in disciplines that would later be labelled as related to "Industry 4.0" (Graf 2020). In 2015 alone, more than 25,000 African students were registered in public and private Malaysian Higher Education Institutions (HEI) (cf. Graf, 2016a).

This paper departs from the observation that most of these students acquire some Malay language skills during their stay in Malaysia, not only as part of their mandatory study programs, but also through various social encounters. This has been leading to a great range of unprecedented linguistic, textual, and cultural phenomena. ${ }^{3}$ This paper discusses notably the changing international role of Malay and the emergence of Malaysia's image both as an international role model of a modern and developed Muslim-majority country as well as a site of vice, prostitution, and danger as in the Ugandan music drama "Malaysia" (2016) performed by the drama group "The Ebonies" in Luganda language. In Malaysia itself, aside of many negative stereotypes, also more positive notions of Africans are occurring in the contemporary Malay-language imaginary, including in the popular Youtube video "Malaysia yang ku cinta" (Malaysia that I love) (2017) sung by Kaiho (i.e. Kaiho Rikambura) from Namibia, as well as in the Malay travelogue on Uganda, Kenya, Rwanda, and Sudan by Dr. Hayya Bilal (i.e. Jamilah Jaafar), Afrika: Aku Mai Lagi (Africa: I come again) (2016). At the same time, the case of Kaiho Rikambura can serve as an example for Malaysia's increasing role as an international reference point for ICT and Industry 4.0, since Kaiho, together with many other pedagogy students on a Namibian government scholarship, studied computer pedagogics in Malaysia (Universiti Pendidikikan Sultan Idris). He then returned to Namibia, teaching computer studies and mathematics at a High School in Windhoek since 2018. ${ }^{4}$

3 Cf. Muhammad Salleh (2009) who points to an earlier wave of spreading the Malay language and Malay literary genres such as the Pantun to South Africa during the Dutch colonial era, while Hamidin Abd. Hamid (2005) focuses more on the historical trajectory from a Malaysian perspective. 


\section{Background: Malaysia as Emerging Hub for International Students}

The financial constraints of the Asia Crisis of 1997-99 on the federal budget of Malaysia caused the Malaysian government not only to decrease spending, but also to look for alternative sources of revenue. Soon, the growing market of Higher Education for internationally mobile students came into the focus of the Ministry of Higher Education. As it was stated in a Powerpoint presentation of the Malaysian Ministry of Higher Education from $2011^{5}$, the purpose was to attract 200,000 international students by the year 2020, each spending RM 30,000 annually. This would generate a total of 6 billion RM for the Malaysian economy, including of course additional revenues for the public and private Higher Education Institutions (HEIs). ${ }^{6}$

Consequently, the responsible Ministry of Higher Education developed a strategy to not only further develop Malaysian HEIs for domestic purposes, but rather to market higher education in Malaysia globally. ${ }^{7}$ This could build on already existing networks established during the 1990s, for instance in Malaysia’s policy towards Africa. ${ }^{8}$ As I have shown elsewhere (Graf, 2016a), Malaysia's niche in international Higher Education is mostly the segment of students from Muslim-majority, Commonwealth, and less-developed countries. In terms of world regions, students from West Asia comprised 24,793 students out of a total of 86,923 international students in the country (ca. 28.5\%), of which more than 1,000 came respectively from Iran $(11,823)$, Yemen $(5,866)$, Saudi Arabia $(2,252)$, and Iraq $(1,835)$. African students comprised the second-largest group with 21,784 students $(=25.1 \%)$, with the bigger cohorts coming from Nigeria $(5,817)$, Libya $(3,930)$, Sudan $(2,837)$, Botswana $(1,911)$, and Somalia $(1,478)$. Southeast Asian students were the third-largest group $(14,663$ or $16.9 \%)$, led by Indonesia $(9,889)$ and Thailand $(1,725)$. There were also 12,298 students from East Asia (ca. 14.1\%), mostly

5 The Powerpoint was available at: http://jpt.mohe.gov.my/menupemasaran.php (retrieved on July 31, 2015; now no longer accessible).

6 Consequently, Chiaw Boon Tian and Haliza Mohd Said (2011) frame their analysis of the experience of international students in Malaysia in terms of the hospitality industry, i.e. tourism.

7 Cf. Samokhvalova $(2015,2017)$ for a detailed discussion on the related strategy and its implication.

8 Cf. Hamidin Abd. Hamid (2003) for a detailed account of Malaysia-Africa relations during the 1990s. 
from China $(10,214)$ and South Korea $(1,725)$. South Asian students $(7,850$ or ca. 9.0\%) came mostly from Bangladesh (2,041), Pakistan (1,789), the Maldives $(1,349)$, India $(1,338)$, and Sri Lanka $(1,103)$. Central Asians were also represented, with 1,782 students (ca. 2.0\%), mostly from Kazakhstan (1,258). From the other world regions, no country had more than 1,000 students in Malaysia. A total of 803 students came from 40 European countries, 255 from eleven countries of South and Central America, 115 from four countries in Oceania, 14 from five countries of the Caribbean, and 2,344 were not identified with a specific home country. ${ }^{9}$

It is understood that these numbers represent a statistical snapshot of the situation in 2010, as far as it was documented in the official calculation of the Ministry of Higher Education. Clearly, the numbers for each country as well the relative share in the total number of international students in Malaysia have been changing every year. The general trend, however, is that from the early 2000s until the beginning of the Covid-19 pandemic the number of international students in Malaysia as well as the number of their countries of origin have been in average constantly rising. In 2003, there were 30,397 enrolled international students from 134 countries in Malaysia, in 2010 the numbers were already 86,923 students from 161 countries (Graf, 2016a, p. 6). In 2016, the Minister for Higher Education, Datuk Seri Idris Jusoh, announced that 151,979 international students were registered in Malaysia in 2015, and he was quoted that "the 200,000 target set for international student enrolment by 2020 in the country would likely be achieved". 10

Due to negative experiences with students (and people who abuse student visa for other, often illegal purposes) from certain African countries (especially Nigeria), the Ministry has been shifting its recruitment emphasis since ca. 2014-15 more to other African and non-African countries. ${ }^{11}$ Also Minister Datuk Seri Idris Jusoh in his quoted statement did not mention Africans as target group specifically, but rather students from "India, China, as well as

9 For the details cf. Graf (2016a, pp. 9-10).

10 New Straits Times. (2016, March 30). https://www.nst.com.my/news/2016/03/136247/internationalstudent-enrolment-12-percent-last-year-higher-education-ministry

11 Personal communication in the Ministry of Education, 2015. Cf. also Samokhvalova (2017) for the related promotional efforts of the Malaysian agencies. Cf. also Röschenthaler (2017a, 2017b) for more insight into the economic activities and cultural horizons of African youths in Malaysia, of whom many officially travel with student visa. 
those from Islamic countries". ${ }^{12}$ Part of this shift is also motivated by growing resentments in the Malaysian public about unruly behavior of certain students from Africa. ${ }^{13}$ Among African students in Malaysia, this has led to more and more experiences of rejection and hostility. ${ }^{14}$

In this paper, however, I would like to focus more on aspects that are not so well covered in existing and forthcoming studies. This concerns especially the dimensions of language and literature/text. With several ten thousand Africans living in Malaysia for several years before almost all of them returned to their home countries, the numerical dimension in this encounter between languages and cultures of Malaysia and Africa is impressive. Dozens of thousand Africans must have already stayed in Malaysia for some time. Almost all of them are enrolled in academic programs where English is the language of instruction. This means that African Englishes and Malaysian Englishes are in a new, unprecedented contact zone. Furthermore, at least at public universities, international students are required to take a minimum of Malay language courses at beginner's level to function within the bilingual setting of most Malaysian public HEIs. Being constantly exposed to Malay language and culture in their everyday lives, many international students, including from Africa, go beyond the officially required minimum level of Bahasa Melayu. In the following, I would like to present some examples of this new dialect of African Malay, which can be of course further differentiated according to the exact language of origin and its encounter with the respective distinct version of Malay.

\section{PABM and the Public Image of "Positive, Malay-Speaking Africans"}

The format of the International Speech Competitions in Malay Language (Pertandingan Pidato Bahasa Melayu, PABM) goes back to an initiative of students

12 New Straits Times. (2016, March 30). https://www.nst.com.my/news/2016/03/136247/internationalstudent-enrolment-12-percent-last-year-higher-education-ministry

13 Cf. Samokhvalova (2017).

14 Cf. Ansah (2016) and Röschenthaler (2017b). Rokis et al. (2017) give an account of intercultural adaptation of African students in Malaysia. 
of the Kolej Kediaman Keempat (Forth Dormitory) of Universiti Malaya in the 1990s and was organized for several years before the Asia Crisis of 1997-8. ${ }^{15}$ About a decade later, one of the former student organizers was involved in relaunching the format at a much higher level, namely as the official PABM for the trophy of the then Deputy Prime Minister of Malaysia, Datuk Seri Najib Tun Razak, in 2007. ${ }^{16}$ When he became Prime Minister of Malaysia in 2009, he continued with the PABM at an even more prominent level. The PABM survived the end of the rule of Prime Minister Datuk Seri Najib Tun Razak in 2018 and is still being organized, despite some challenges due to the Covid-19 pandemic. The final round of the PABM is traditionally broadcast nationwide at prime time, namely Friday evening. As I have discussed the nexus between rhetoric and politics at the Malaysian PABM elsewhere (Graf, 2011), I would like to focus here more on the role of African participants in this Malaylanguage speech competition and on their public image as "positive, Malayspeaking Africans" - which is somewhat in contrast to negative tendencies in the framing of Africans in Malaysian media (Ahmad, 2017).

A good example for the framing of African participants in PABM is the media coverage of the final round of the PABM 2016, when Abdalla Hassan Ghorib $^{17}$ from Tanzania won the first prize in the category of International Students. As Samokhvalova (2016) observes:

"Abdalla Hassan from Tanzania ... attracted attention of the audience with his excellent speech. Moreover, he managed to win the hearts of the Prime Minister and his wife as he parodied Najib's voice and way of speaking as a part of his performance", wrote one of the main state newspapers (http:// www.utusan.com.my/rencana/syabas-pabm-2016-1.205558\#sthash. LnJown... ). Another major online periodical posted a video of him explaining to the camera how he loved Malay language and wished to

15 I myself participated at the PABM of Universiti Malaya in 1996, as representative of Germany.

16 In 2007, 2008, and 2009 I participated as judge of the final rounds of the PABM when I encountered the former student from Universiti Malaya again and where I learned about the career of the concept of the PABM.

17 In some Malaysian media also spelled Abdallah Hassan Gharib (cf. https://www. google.de/search? q=Abdallah + Hassan+pabm\&client=firefox-b\&source =1 $\mathrm{nms} \& \mathrm{tb} \mathrm{m}=\mathrm{isch} \& \mathrm{sa}=\mathrm{X} \& \mathrm{ved}=0 \mathrm{ahUKEw}$ is o J f L z L U U h W EXRQKHV 1 x CV 4 Q AUICygC\&biw=1680\&bih=917\#imgrc=10riOMblF0Wl0M:, retrieved on June 13, 2017). 
master all nuances of it to speak like the native borns - a delight for the ears of the Malaysian audience (Samokhvalova, 2016).

Samokhvalova (2016) identifies here important elements for a positive public perception of Africans in the spheres of government, state media, and wider public: The basis is an excellent mastery of Malay at the level of public oratory, combined with a sense of politically correct humor and an open declaration of affection for Malay language and culture. It can be said that the PBAM helps to generate this positive image of Africans not only in the case of the PABM 2016 when Abdallah Hassan won. Also at the occasion of other PABM, the Malay language skills of African participants amazed the reporting media. An example is the headline of Utusan Online, a media linked to the long-time ruling party UMNO (United Malays National Organization), about the PABM 2014: "Kualiti Bahasa Melayu peserta Afrika, Timur Tengah mengagumkan" (The quality of the Malay of the participants from Africa and the Middle East is amazing). ${ }^{18}$

\section{From PABM to Youtube to Online Film: Kaiho and New Niches for Africans in the Malay Imaginary}

The representative from Namibia at the PABM 2016, Kaiho Rikambura, continued to develop this positive image of Malay-speaking Africans even further when he starred in a popular Youtube music clip in 2017, entitled "Malaysia yang ku cinta" (Malaysia that I love). ${ }^{19}$ The lyrics of Kaiho's song "Malaysia yang ku cinta" are available online. ${ }^{20}$ Kaiho is also featuring in the online documentary "Malaysia for me is..."21, which gives various personal perspectives of African students in Malaysia. The film was produced by Melanie Gärtner with the research support of Alexandra Samokhvalova, and

$18 \mathrm{http} / /$ xtive.utusan.com.my/video.php?v=1519, link to the video broken as of June 12, 2017.

19 https://www.youtube.com/watch?v=8cup3xUJj9o. As of 12 June 2017, the clip already had 136,845 hits.

20 https://ohlirik.com/lirik-lagu-malaysia-yang-ku-cinta-kaiho/. The Malaysian newspaper The Star published online a biographical story about Kaiho on June 14, 2017 (https://www.thestar.com.my/ lifestyle/people/2017/06/14/omar-kaiho-cinta-kholdi).

21 https://www.youtube.com/watch?v=vntHx0iu-YY 
financed through the research project AFRASO (Africa's Asian Options) of the Federal Ministry of Education and Research of Germany, which, however, had no influence on the content of the film itself. ${ }^{22}$ In her interviews with Kaiho, Alexandra Samokhvalova found out that he was among around 100 students of IT pedagogy with scholarships of the Government of Namibia. ${ }^{23}$ They were supposed to learn at Universiti Pendidikan Sultan Idris in Malaysia the state of the art of computer and information technology for schools, to be applied in government schools in Namibia. In the meantime, Kaiho Rikambura has returned to Namibia, teaching computer studies at Cosmos High School in Windhoek since 2018 . $^{24}$

The lyrics of Kaiho's song "Malaysia yang ku cinta" are available online. ${ }^{25}$ It was not Kaiho who wrote them, but a Malaysian with the pen name "Room None" who is otherwise known as the author of several other Malay song lyrics, sometimes with reference to Muslim events such as lebaran (celebrating the end of Ramadhan). ${ }^{26}$ It can be thus safely assumed that the author is writing for a Malay, Muslim audience. The Malay lyrics for the African singer would therefore mostly reflect pre-existing images and stereotypes of the audience.

The song "Malaysia yang ku cinta" consists of four main stanzas, each with a different sub-topos of the overall topos "Malaysia", followed by the refrain "Malaysia yang kucinta / Malaysia yang kupuja" (Malaysia that I love/Malaysia that I praise), sung twice. The first of these four stanzas introduces the singer and his relation to the country: "Tanpa sedar tiga tahun / Ku sudah disini / Betapa indah negeri ini / Berbilang bangsa dan kaum yang ada disini /Semua saling menghormati" (I did not realize that three years / I am already here / How beautiful this country is / Various races and ethnic groups that are here / All respect each other). The admiration for the general beauty of the country is thus directly linked to the alleged harmony and mutual respect of the ethnic groups of Malaysia.

In the second stanza, the general theme of a multicultural Malaysia is

22 http://xtive.utusan.com.my/video.php?v=1519, link to the video broken as of June 12, 2017.

23 https://www.youtube.com/watch? $\mathrm{v}=8$ cup3xUJj9o. As of 12 June 2017, the clip already had 136,845 hits.

24 https://ohlirik.com/lirik-lagu-malaysia-yang-ku-cinta-kaiho/. The Malaysian newspaper The Star published online a biographical story about Kaiho on 14 June, 2017 (https://www.thestar.com.my/ lifestyle/people/2017/06/14/omar-kaiho-cinta-kholdi).

25 https://www.youtube.com/watch?v=vntHx0iu-YY

26 https://www.youtube.com/watch?v=vntHx0iu-YY 
continued, this time in the field of food: "Pelbagai menu sarapan menjadi tarikan / Semua sangat menyelerakan / Roti canai ada roti telur ada nasi lemak ada nasi kandar ada semua ada / Itulah semua keindahan" (Various menues are attractive / All of them taste very good / There is roti canai ${ }^{27}$ there is roti telur ${ }^{28}$ there is nasi lemak ${ }^{29}$ there is nasi kandar ${ }^{30}$ there is everything / All of it is so beautiful). In difference to the first stanza, the mentioned dishes refer mostly to a MalayMuslim taste, while Chinese or Hindu-Indian dishes are not mentioned here.

The following stanza continues with the theme of delicious Malaysian food, but widens the scope from food mostly associated with the MalayMuslim majority to an inclusion of notably the Indian and Chinese groups: "Salah satu yang ku suka / Pelbagai juadah bila di musim perayaan / Aidilfitri Deepavali dan go fi xa chai / Semua saling merayakan" (One thing that I like is / Various yummy foods in the festive season / Aidilfitri Deepavali Go Fi Xa Chai / All are celebrating each other).

The final stanza shifts the attention from the attractive food to the beauty of Malay girls: "Siapa bilang gadis Melayu tidak menawan / Tapi hatiku tertawan / Cantiknya Si Cikgu Ayu / Kau pikat hatiku / Kuingin disini selalu" (Who said that Malay girls are not pleasant and tempting / But my heart is captured / By the beauty of the Pretty Teacher / You captivate me / I want to stay here forever). The figure of "Si Cikgu Ayu" refers to the song "Cikgu Ayu" of the band Khalifah, ${ }^{31}$ the lyrics being by Yabang. Several of the members of the band Khalifah feature also in the Youtube video of Kaiho's "Malaysia yang ku cinta", and there are also several video clips of Kaiho performing with that band in singing their song "Hang pi mana". ${ }^{32}$ Furthermore, in the introductory sequence of Kaiho's "Malaysia yang ku cinta", he is being asked by hawkers "Hang pi mana?" - which is of course yet another reference to Khalifah. According to Paola Kira Ewusi in Sinar Harian Online, it was Kaiho's performance with Khalifah in "Hang Pi Mana" that made the singer

27 Indian-influenced flatbread. This and the following explanations of the mentioned Malaysian dishes are based on entries in Wikipedia.org.

28 Another version of Roti Canai, with fried eggs.

29 Malay fragrant rice dish cooked in coconut milk and pandan leaf.

30 Popular dish with steamed rice served with a variety of curries and side dishes.

31 https://www.youtube.com/watch?v=MtTfAbMz7-E

32 E.g. https://www.youtube.com/watch?v=FWOiJSLIxCw, or https://www.youtube.com/ watch?v=Wp0q8-t4LjA 
popular in Malaysia. ${ }^{33}$

To summarize, the main topoi of Kaiho's song "Malaysia yang ku cinta" are 1) the beauty of the country and its multicultural harmony, 2) the delicious Malay-Muslim food, 3) the delicious food of the Chinese and Indians, and 4) the highly attractive Malay girls. This image of "African" interest in Malay/ Malaysian culture is thus mostly determined by physical aspects, while we have to keep in mind that this image is being constructed by a Malay textwriter, revealing probably a lot about pre-conceptions of "Africans".

It is interesting to see that Kaiho in other contributions to his public image in Malaysia is not only emphasizing on the physical side, but also on spiritual aspects. The article in Sinar Harian Online from January 2017 features for instance in this regard that Kaiho converted to Islam in September 2016. ${ }^{34}$ On his Facebook page, he also describes his experiences with Ramadhan in Malaysia. ${ }^{35}$ His multimedia career in Malay popular culture is further advanced through his first appearance in the Internet telefilm "Cinta Kholdi" (first released 5 June 2017) where he starred together with actress and singer Aishah Hasnaa. ${ }^{36}$ In his Malay language Facebook page, Kaiho advertises this as follows: "Besok tonton Blackman cuba acting.. jangan lupa kasi advice okk" (Tomorrow watch how Blackman tries to act.. don't forget to give advice ok). ${ }^{37}$

In sum, it appears that with Kaiho the first more prominent, positive African figure is emerging in Malay-language popular culture, as an unintended side-effect of the efforts of the Malaysian government to make Malaysia a hub of international Higher Education. An important contributing factor for the construction of such positive public figures from foreign countries are the PABM speech competitions in Malay language. They provide a good opportunity of presenting a positive image of foreigners to the Malay TV audience. The constraints of the format of a Malay-language speech competition are that the stereotype of a "positive foreigner" (or "positive

33 http://www.sinarharian.com.my/hiburan/hang-pi-mana-popularkan-omar-1.613774

34 https://www.youtube.com/watch?v=MtTfAbMz7-E

35 E.g. https://www.youtube.com/watch?v=FWOiJSLIxCw, or https://www.youtube.com/ watch?v=Wp0q8-t4LjA

$36 \mathrm{http}: / / w w w . s i n a r h a r i a n . c o m . m y / h i b u r a n / h a n g-p i-m a n a-p o p u l a r k a n-o m a r-1.613774$

37 http://www.sinarharian.com.my/hiburan/hang-pi-mana-popularkan-omar-1.613774 
African") implies the mastery of the Malay language, and the acquaintance with Malay cultural values.

\section{5. "Siapa bilang gadis Melayu tidak menawan" - Personal Malay-African Encounters}

While in Kaiho's song "Malaysia yang ku cinta" admittedly a part of his love for the host country comes from his love for the Pretty Teacher (Cikgu Ayu), also the plot of the telemovie "Cinta Kholdi" (2017) emphasizes on the love story between a Muslim African man (played by Kaiho) and a Muslim Malay woman (played by Aishah Hasnaa). On the website of the production company, the synopsis of the film is given as follows:

Illustration 1: Book cover of Dr. Hayya Bilal's first book $^{40}$

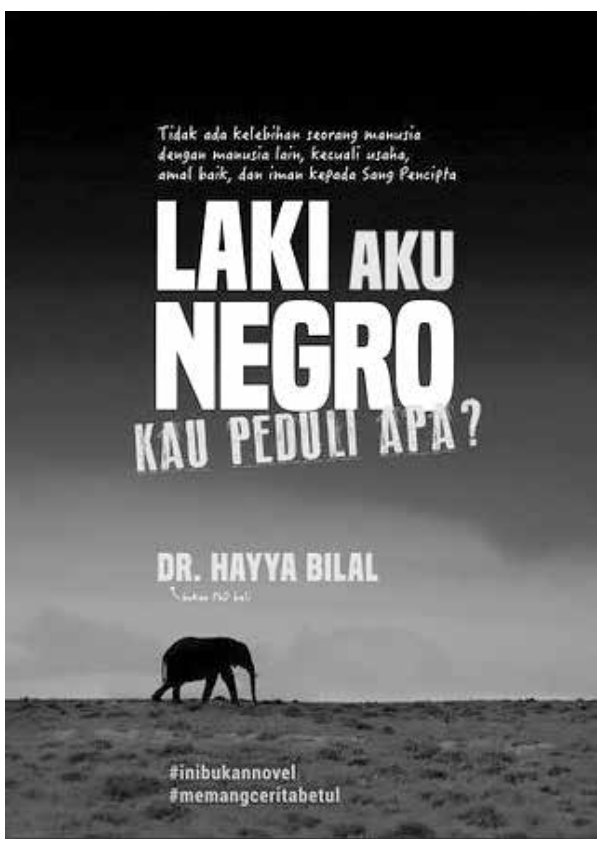

Cinta itu buta dan tidak mengenal warna kulit. Wani memperkenalkan Kholdi kepada ibu bapanya supaya mereka dapat menerima Kholdi sebagai menantu. Tapi malangnya sesuatu berlaku? Dapatkah Kholdi dan Wani bersatu. ${ }^{38}$

(Love is blind and does not recognize skin color. Wani introduces Kholdi to her parents so that they can accept him as son-in-law. But unfortunately something happens. Can Kholdi and Wani be together?)

In fact, in Malay popular

38 http://www.myinfotaip.com/2017/06/cinta-kholdi.html

39 http://www.goodreads.com/review/show/1650003675

40 From https://www.goodreads.com/book/show/29739940-laki-aku-negro-kau-peduli-apa 
culture of the mid-2010s it is not only the public figure of Kaiho that plays an important role in discussing mixed relations between African students and Malays. Important contributions to this new discursive Malay-African sphere also come from Dr. Hayya Bilal (pen name of Dr. Jamilah Jaafar). Her first, autobiographic book is entitled Laki Aku Negro - Kau Peduli Apa? (My Man Is a Negro - Why Do You Care?). It discusses mainly issues of her personal relationship with her husband from Uganda in their cultural context, including often negative or racist reactions. Most readers' comments on Goodreads. com appreciate this critical discussion of racist attitudes towards Africans in Malaysia. $^{39}$

\section{From Autobiography to Travelogue to Scientific Exploration}

Hayya Bilal's second book, Afrika: Aku Mai Lagi (Africa: I come again), constitutes the first contemporary Malay-language travelogue of Africa and marks as such an important development in the Malay imagination of Africa. The book is framed in the narrative of personal travel experiences of the author in Africa, but it also covers anthropological, historical, political, and social aspects of Africa. In fact, the author is trained academically and holds a PhD from the International Islamic University Malaysia (IIUM). The topic of her PhD thesis in the Institute of Education (under her real name Jamilah Jafaar) was "Interactions among environment, achievement, behavior and personal attributes of Malaysian secondary school boys: a structural equation modeling study" (2012). ${ }^{41}$ Currently, the author works for the Malaysian Ministry of Education. ${ }^{42}$

As the author is academically trained and has the personal background of being married to an African academic from Uganda (who studied in Malaysia) for many years, the book goes far beyond any common clichés about Africa that might be found otherwise in Malay popular culture. It also surpasses

41 The Worldcat entry spells "achievenent" as "achivement" (cf. http://www.worldcat.org/title/ interactions-among-environment-achivement-behaviour-and-personal-attributes-of-malaysiansecondary-school-boys-a-structural-equation-modeling-study/oclc/957323415\&referer=brief_ results).

42 Cf. her Facebook page https://www.facebook.com/public/Jamilah-Jaafar 
Illustration 2: Book cover of Dr. Hayya Bilal's second book ${ }^{43}$

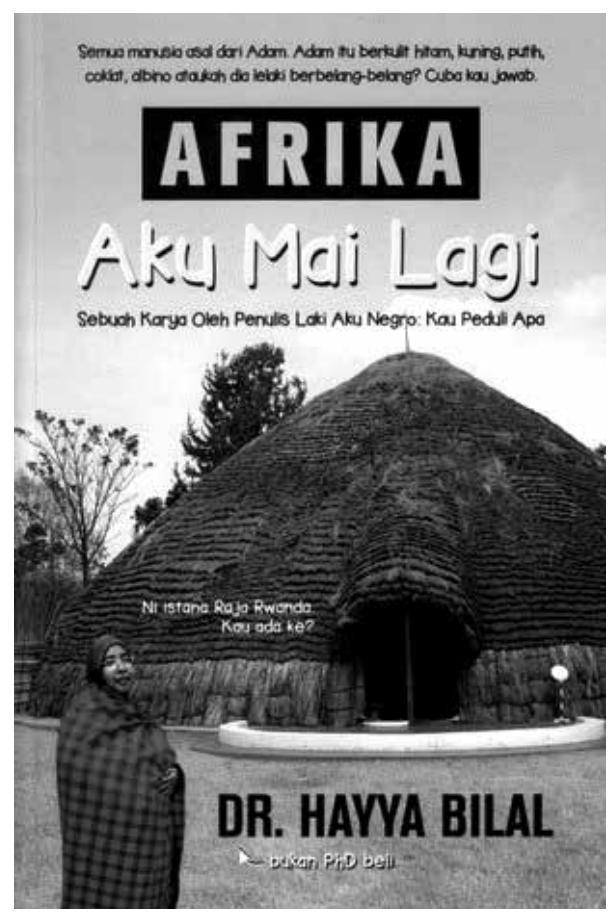

most Western constructions of "traditional Malay stereotypes" which often do not take into account that the high emphasis on education in Malaysia since the 1970s has produced an intellectual curiosity and openness in many quarters in the country that increasingly go far beyond the limitations and identity discourses left by British colonialism.

Rather, the book constitutes an attempt to explain to the Malay audience key elements of culture and society of Uganda, Kenya, Rwanda, and Sudan in a sympathetic, often humorous way. This includes for every country a description of important museums, libraries, and buildings. Based on the

displays and the stories related to them, she tries to connect aspects of African culture with phenomena in the Malay world, e.g. African shamans and healers in comparison to Malay bomoh. There, she is often referring to preIslamic layers of Malay culture. Other aspects covered include discussions of British colonialism in Africa, the condition of railways, roads, electricity grids, political aspects such as Idi Amin, the genocide in Rwanda, inter-ethnic conflicts in Africa etc. Also lifestyle issues are being portrayed, including African hairstyles, culinary encounters, and humorous events. One of her chapters is entitled "I am a nasi eater", where she is discussing special MalayAfrican intercultural experiences. 


\section{Malaysia's Multifaceted Image in Texts by African Authors}

Illustration 3: Poster of the play "Malaysia" at Theatre La Bonita, Kampala, Uganda ${ }^{44}$

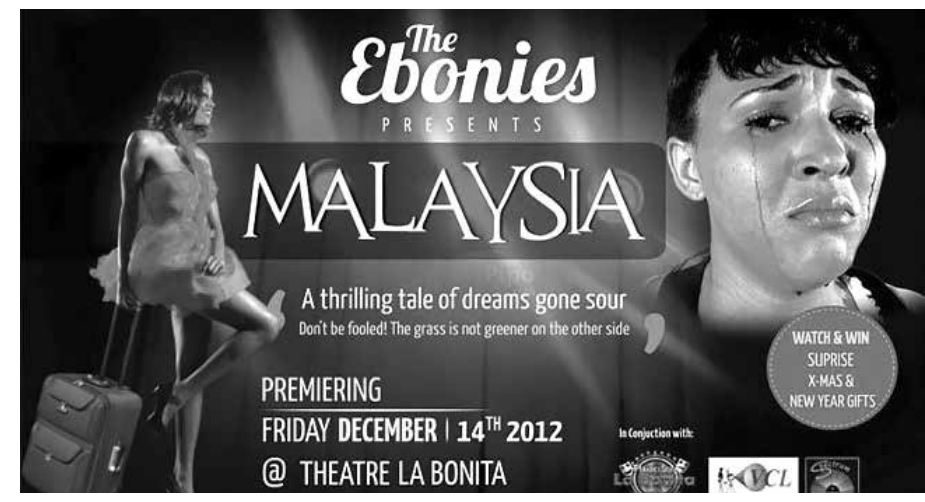

Hayya Bilal's account also includes an encounter with a negative image of Malaysia in certain parts of Africa and might be as such an important feedback for Malaysian discourses about the international perception of the country. As Hayya Bilal describes in Afrika: Aku Mai Lagi, on one of her trips to Uganda, she sees a poster of a theatre play staged in Kampala and entitled "Malaysia A thrilling tale of dreams gone sour". According to her description, she learns from her husband that the plot of the theatre piece is about young female Ugandans who are being lured to Malaysia, but then forced into prostitution once there. Although the title of the play on the poster is in English, according to Hayya Bilal, the real stage language is Lugandan which she cannot understand (Bilal, 2016b, p. 53).

In fact, the play seems to have been staged the first time only a few months before Hayya Bilal published her book in December 2016. The theatre group, “The Ebonies", claims to be "Uganda's best known drama group" on its Facebook page. ${ }^{45}$ According to an article by Felix Eupal in The Observer (Kampala), "The Ebonies" showed "Malaysia” for the first time over Easter 2016, with performances twice a day. The article explains some of the background further:

44 From https://www.goodreads.com/book/show/34003052-afrika

45 https://www.facebook.com/ebonies256/ 
"A lot has been happening as many of our brothers and sisters try to make ends meet by going to different countries in search of work," says Ebonies director Sam Bagenda. He adds that "the tabloids have let out just the tip of what happens, and we have done enough research to come out with a play that explains what really happens to those who fly out in search for greener pastures."

The play focuses on how girls are turned into sex workers and how others actually get to like what they are doing. It further gives the story of what the men get to do, because most of the attention is usually placed on the girls. ${ }^{46}$

\section{Conclusion}

As I have demonstrated so far, there is a relevant new Malay-African sphere that emerged mostly due to the migration of tens of thousands of African students to Malaysia since the early 2000s. There are new linguistic encounters both of African and Malaysian Englishes as well as between African languages and Malay. This includes that already several Africans are excelling in Malay oratory, and that the first Africans are now being starred in Malay-language films. Furthermore, there are now Malay-language accounts about not only personal relations with Africans, but also proto-scientific descriptions of African culture and society. In fact, as I have shown elsewhere, since around 2006-2008, the number of scientific journal articles by Africans on Southeast Asia, and by Southeast Asians on Africa, is growing fast (Graf, 2016b). The logical next step in this encounter between Malaysia and Africa could be the establishment of an African Studies Centre at a Malaysian university, as Malaysia already hosts the secretariat of the Asia Africa Development University Network (AADUN) at Universiti Malaya.

Such a Centre of African Studies in Malaysia would be the first one in Southeast Asia, and its existence would be justified by the intensive exchanges and encounter between Malaysia and Africa. In the field of Higher Education, 
this includes also the establishment of branch campuses of Malaysian universities in Africa. Well-known is the example of the Limkokwing University of Creative Technology, which so far established branch campuses in four African countries (Lesotho, Swaziland, Botswana, and Sierra Leone), targeting what it calls "Africa's middle-class boom". ${ }^{47}$

In this regard, there are not only new grounds for Malay as international language, but also for Malaysian Studies and Southeast Asian Studies in general.

\section{Funding}

Research for the article has been supported by the research project "AFRASO - Africa's Asian Options", funded by the German Federal Ministry of Education and Research (BMBF), 2013-2019.

\section{References}

Ahmad, Abdul Latiff. (2017). Pemaparan warga Afrika di dalam Berita Harian [The representation of Africans in Berita Harian]. e-Bangi: Journal of Social Sciences and Humanities, 14(3), 1-11. https://ejournal.ukm.my/ebangi/article/view/22503

Ansah, Eric Schubert. (2016). Conceptualizing African migration to South-East Asia: Student, trader, businessman and the future of policy in Malaysia. e-Bangi: Journal of Social Sciences and Humanities, 11(1), 59-90. http://www.myjurnal.my/public/article-view. php?id=101421

Bilal, Hayya (i.e. Jamilah Jaafar). (2016a). Laki aku negro - Kau peduli apa? [My man is a negro - why do you care?]. Puteh Press.

Bilal, Hayya. (2016b). Afrika - Aku Mai Lagi [Africa: I come again]. Jamilah Jaffar.

Chiew, Boon Tian and Haliza Mohd Said. (2011). International students' travel experience and preference towards hospitality services during holidays in Malaysia. Universiti Tun Abdul Razak e-Journal, 7(1), 39-56. http://www.myjurnal.my/public/article-view.php?id=70236

Graf, Arndt. (2020). Challenges for the preservation of the Malay language in the imminence

47 https://www.limkokwing.net/transform_africa/ 
of the Fourth Industrial Revolution (Cabaran pelestarian Bahasa Melayu menjelang Revolusi Industri Keempat). Melayu: Jurnal Antarabangsa Dunia Melayu, 13(1), 161-172. http://jurnal.dbp.my/index.php/Melayu/article/view/5776

Graf, Arndt. (2016a). Malaysia’s niche in international higher education: Targeting Muslimmajority, Commonwealth, and less-developed countries. TRaNS: Trans-Regional and -National Studies of Southeast Asia, 4(1), 5-40. https://doi.org/10.1017/trn.2015.16

Graf, Arndt. (2016b, September 16-18). Discovering an unknown continent. The rise of ISIindexed publications on Africa by authors from Southeast Asia, 1989-2016 [Paper presentation]. ASEASUK Conference, SOAS, London, United Kingdom.

Graf, Arndt. (2011). Rhetoric and politics at the International Speech Competitions in Malay Language (PABM). Indonesia and the Malay World, 39(114), 295-316.

Graf, Arndt and Azirah Hashim (Eds.). (2017). African-Asian Encounters. New Cooperations and New Dependencies. Amsterdam University Press.

Hamidin Abd. Hamid. (2009). Malaysia-Africa relations: emerging trends. Sarjana, 24(2), 2948. http://www.myjurnal.my/public/article-view.php?id=206

Hamidin Abd. Hamid. (2005). Emosi Melayu: Melayu dan perhambaan di Cape, 1652-1838 [Malay emotions: Malays and slavery at the Cape]. Jurnal pengajian Melayu, 1, 116-131. http://www.myjurnal.my/public/article-view.php?id=72315

Hamidin Abd. Hamid. (2003). In pursuit of equality: Malaysia-Africa relations in the 1990s. JATI: Journal of Southeast Asian Studies, 8, 67-84. http://www.myjurnal.my/public/articleview.php?id=67738

Malaysia, Ministry of Higher Education. (2012). Malaysia Education Blueprint 2015-2025 (Higher Education). https://www.um.edu.my/docs/default-source/about-um_document/ media-centre/um-magazine/4-executive-summary-pppm-2015-2025.pdf? $\mathrm{sfvrsn}=4$

Salleh, Muhammad Haji. (2009). Words over borders: trafficking literatures in Southeast Asia. Asiatic: IIUM Journal of English Language and Literature, 3(2), 1-24. http://www.myjurnal. my/public/article-view.php?id=14787

Röschenthaler, Ute. (2017a). In constant search of money to survive: African youths in Malaysia. In Arndt Graf \& Azirah Hashim (Eds.), Asian-African Encounters. New Cooperations and New Dependencies (pp. 17-45). Amsterdam University Press.

Röschenthaler, Ute. (2017b). African Businesses in Malaysia: 'You just have to be smart' to survive. In Ute Röschenthaler \& Alessandro Jedlowski (Eds.), Mobility between Africa, Asia and Latin America: Economic Networks, Cultural Interaction and Aspirations of Success (pp. 156-180). Zed Books.

Rohaiza Rokis, Norhidayah Mat Zain and Nur Fatihah Md. Yusuf. (2017). A preliminary understanding on intercultural adaptation among African students in Malaysia: a 
groundwork study. Journal of Advanced Research in Social and Behavioural Sciences, 9(2), 9-19. http://irep.iium.edu.my/60919/

Samokhvalova, Alexandra. (2017). Branding higher education: The case of Malaysian higher education promotion on the Internet, Kajian Malaysia, 35(2), 87-104.

Samokhvalova, Alexandra. (2016). Student from Tanzania Wins the International Malay Language Speech Competition: Some Good Publicity for Africans in Malaysia in the End?. http://www.afraso.org/en/content/student-tanzania-wins-international-malay-languagespeech-competition-some-good-publicity

Samokhvalova, Alexandra. (2015). Transformation of the Higher Education System in Malaysia: APEX Initiative and World Class University. Universiti Sains Islam Malaysia Press.

\section{Professional Profile}

Arndt Graf has been Professor of Southeast Asian Studies at Goethe University of Frankfurt, Germany, since 2009, and Adjunct Professor at Universiti Pendidikan Sultan Idris, Malaysia, since 2021. He also held visiting positions at Cornell University, the State Islamic University Jakarta, the University de La Rochelle, France, and Universiti Malaya. He has a PhD on the topic of "Austronesian Languages and Cultures" from the University of Hamburg in 1998. His academic publications are primarily on aspects of rhetoric, media, and political communication in insular Southeast Asia. 